medRxiv preprint doi: https://doi.org/10.1101/2020.10.02.20205708; this version posted October 5, 2020. The copyright holder for this preprint (which was not certified by peer review) is the author/funder, who has granted medRxiv a license to display the preprint in perpetuity.

SARS-CoV-2 antigen testing and infectiousness

\title{
Antigen-based testing but not real-time PCR correlates with SARS-CoV-2 virus culture
}

Andrew Pekosz, PhD, ${ }^{1.2}$ Charles K. Cooper, MD ${ }^{3}$ Valentin Parvu, PhD, ${ }^{3}$ Maggie Li, MS, ${ }^{1}$ Jeffrey C. Andrews, MD, ${ }^{3}$ Yukari C. Manabe, MD, ${ }^{1,4}$ Salma Kodsi, MS, ${ }^{3}$ Jeffry Leitch, PhD, ${ }^{3}$ Devin S. Gary, $\mathrm{PhD},{ }^{3}$ Celine Roger-Dalbert, $\mathrm{MS}^{3}$

${ }^{1}$ W. Harry Feinstone Department of Molecular Microbiology and Immunology, Johns Hopkins Bloomberg School of Public Health, ${ }^{2}$ Department of Emergency Medicine

${ }^{3}$ Becton, Dickinson and Company, BD Life Sciences - Integrated Diagnostic Solutions, 7

Loveton Circle, Sparks, MD, USA,

${ }^{4}$ Department of Medicine, Johns Hopkins University School of Medicine, Baltimore, Maryland

\#To whom correspondence should be addressed:

Andrew Pekosz, PhD

615 N. Wolfe Street

Room W2116

Baltimore, Maryland 21205

Phone: 410-502-9306

Email: apekosz1@jhu.edu

Charles K. Cooper, MD

Vice President of Medical Affairs

Becton, Dickinson and Company, BD Life Sciences - Integrated Diagnostic Solutions

7 Loveton Circle, Sparks MD 21152, USA

Phone: 410-316-4984

E-mail: Charles_K_Cooper@bd.com

\section{WORD COUNT}

1,668 (Introduction, Results, and Discussion); 942 (Methods)

KEY WORDS: SARS-CoV-2; Antigen testing; SARS-CoV-2 contagious; viral load; live culture; RT-PCR testing

RUNNING TITLE: SARS-CoV-2 antigen testing and infectiousness 
medRxiv preprint doi: https://doi.org/10.1101/2020.10.02.20205708; this version posted October 5, 2020. The copyright holder for this preprint (which was not certified by peer review) is the author/funder, who has granted medRxiv a license to display the preprint in perpetuity. SARS-CoV-2 antigen testing and infectiousness

\section{SUMMARY}

2 Individuals can test positive for SARS-CoV-2 by real-time polymerase chain reaction (RT-PCR)

3 after no longer being infectious. ${ }^{1-8}$ Positive SARS-CoV-2 antigen-based testing exhibits a

4 temporal pattern that corresponds with active, replicating virus and could therefore be a more

5 accurate predictor of an individual's potential to transmit SARS-CoV-2. ${ }^{2,3,9}$ Using the BD

6 Veritor System for Rapid Detection of SARS-CoV-2 later flow antigen detection test, we

7 demonstrate a higher concordance of antigen-positive test results with the presence of cultured,

8 infectious virus when compared to RT-PCR. When compared to infectious virus isolation, the

9 sensitivity of antigen-based testing is similar to RT-PCR. The correlation between SARS-CoV-2

10 antigen and SARS-CoV-2 culture represents a significant advancement in determining the risk

11 for potential transmissibility beyond that which can be achieved by detection of SARS-CoV-2

12 genomic RNA. Coupled with a rapid time-to-result, low cost, and scalability, antigen-based

13 testing should facilitate effective implementation of testing and public health interventions that

14 will better contain COVID-19. 
medRxiv preprint doi: https://doi.org/10.1101/2020.10.02.20205708; this version posted October 5, 2020. The copyright holder for this preprint (which was not certified by peer review) is the author/funder, who has granted medRxiv a license to display the preprint in perpetuity.

SARS-CoV-2 antigen testing and infectiousness

\section{INTRODUCTION}

16 The SARS-CoV-2 causes COVID-19 and is spread from human-to-human primarily through

17 airborne transmission. ${ }^{10}$ The mean incubation time, or presymptomatic period, for SARS-CoV-2

18 is approximately 5.8 days (95\% CI 5.0-6.7), ${ }^{11,12}$ and the period of transmission (the total time

19 during which a patient is contagious) begins around one to three days prior to symptom onset,

20 with a subsequent reduction in contagiousness occurring 7-10 days following symptom

21 onset. $^{8,13,14}$ Recent work in a golden hamster SARS-CoV-2 model demonstrated that although the

22 presence of genomic RNA in nasal washes extends to 14 days post-inoculation, the detection of

23 infectious virus and the communicable period both end well before 14 days. ${ }^{15}$ In addition, four

24 previous studies, utilizing culture-based virus detection from human specimens, demonstrated an

25 absence of infectious isolates from most specimens taken eight days after symptom onset, despite

26 measurable viral RNA loads using RT-PCR. ${ }^{1,3,5,7}$

28 Several SARS-CoV-2 antigen-based tests, which work via a lateral flow immunoassay

29 mechanism, have recently received Emergency Use Authorization (EUA) from the Food and

30 Drug Administration. ${ }^{16-19}$ Several lines of indirect evidence suggest that antigen-based testing

31 may align better with culture-based test results compared to RT-PCR. For example, higher RT-

32 PCR Ct values from specimens are observed when individuals are negative by antigen testing or

33 culture-based testing compared to those from individual that are antigen test ${ }^{9}$ or culture-based

34 test positive. ${ }^{6}$ In addition, current EUA SARS-CoV-2 antigen tests have optimal performance

35 profiles $^{16-19}$ at time points that overlap with the temporal expression profile of SARS-CoV-2 sub-

36 genomic RNA (a marker for active, replicating virus). ${ }^{3}$ Despite the recognition that point-of-care

37 or other testing modalities might be more effective at discerning contagious from non-contagious 
medRxiv preprint doi: https://doi.org/10.1101/2020.10.02.20205708; this version posted October 5, 2020. The copyright holder for this preprint (which was not certified by peer review) is the author/funder, who has granted medRxiv a license to display the preprint in perpetuity. SARS-CoV-2 antigen testing and infectiousness

38 individuals, ${ }^{2}$ no study has directly compared antigen-based testing with RT-PCR in the same

39 study using a reference method for infectiousness.

40

41 The objective of this study was to determine whether SARS-CoV-2 antigen testing differentiates

42 SARS-CoV-2-contagious individuals (e.g., those still shedding infectious virus) from non-

43 contagious individuals compared to RT-PCR methodology. To address this, we utilized Quidel

44 Lyra ${ }^{\circledR}$ SARS-CoV-2 Assay ("RT-PCR assay") positive and negative specimens obtained from a

45 diverse set of collection sites across the USA. The RT-PCR assay and the BD Veritor ${ }^{\mathrm{TM}}$ System

46 for Rapid Detection of SARS-CoV-2 (“antigen test") were compared to SARS-CoV-2

47 TMPRSS2 culture (a sensitive virus culture test utilizing the VeroE6TMPRSS2 cell line), which

48 served as the reference method for determining infectiousness. 
medRxiv preprint doi: https://doi.org/10.1101/2020.10.02.20205708; this version posted October 5, 2020. The copyright holder for this preprint (which was not certified by peer review) is the author/funder, who has granted medRxiv a license to display the preprint in perpetuity.

SARS-CoV-2 antigen testing and infectiousness

\section{RESULTS}

50 The 38 RT-PCR positive specimens were tested for the presence of SARS-CoV-2 using infection

51 of VeroE6TMPRSS2 cell cultures (SARS-CoV-2 TMPRSS2 culture). Overall, 28 RT-PCR-

52 positive specimens were also positive by SARS-CoV-2 TMPRSS2 culture and 10 of 38 RT-

53 PCR-positive specimens were negative by SARS-CoV-2 TMPRSS2 culture (Figure 1A). SARS-

54 CoV-2 TMPRSS2 culture-positive specimens had a mean log10 viral RNA copy number of 7.16

55 compared to 4.01 from specimens that were SARS-CoV-2 TMPRSS2 culture-negative (p-value

$56<0.001$; two-sample t-test, 2-tailed analysis). Further stratification by results from the antigen test

57 showed that 27 of 28 RT-PCR-positive/SARS-CoV-2 TMPRSS2 culture-positive specimens

58 were also positive in the antigen test; only two of the ten RT-PCR-positive/ SARS-CoV-2

59 TMPRSS2 culture-negative specimens were positive by the antigen test.

60

61 Of the 38 RT-PCR-positive results utilized for these analyses, nine were antigen test negative.

62 These nine negative results showed a trend towards longer time from symptom onset compared

63 to the 29 RT-PCR assay-positive/antigen test-positive specimens (4.4 days on average versus

$642.9, \mathrm{p}$-value $=0.108) .{ }^{9}$ Of the nine samples that were RT-PCR-positive/antigen test-negative, the

65 viral RNA copy number was significantly lower than that observed for the 29 RT-PCR-

66 positive/antigen test-positive specimens (mean $4.3 \log 10 \mathrm{cp} / \mathrm{mL}$ versus $7.0 \log 10 \mathrm{cp} / \mathrm{mL}$, p-

67 value $<0.001$, Figure S1). Symptom day was not a significant factor in multivariate models, while

68 viral RNA load continued to be significant ( $\mathrm{p}$-value $=0.002)$.

69

70 Probit models for percent positivity by viral RNA load corresponding to the RT-PCR assay,

71 antigen test, SARS-CoV-2 TMPRSS2 culture, and SARS-CoV-2 culture with VeroE6 cells 
medRxiv preprint doi: https://doi.org/10.1101/2020.10.02.20205708; this version posted October 5, 2020. The copyright holder for this preprint (which was not certified by peer review) is the author/funder, who has granted medRxiv a license to display the preprint in perpetuity.

SARS-CoV-2 antigen testing and infectiousness

72 ("SARS-CoV-2 VeroE6 culture;" data integrated into the probit model using previous data; see

73 Methods $)^{6}$ are provided in Figure 1B. The SARS-CoV-2 VeroE6 culture yielded a positive result

74 at a rate of $5 \%$ for a viral $\operatorname{load}$ of $5.75 \log 10 \mathrm{cp} / \mathrm{ml}$, whereas the SARS-CoV-2 TMPRSS2 culture

75 corresponded to a positive result with a rate of $5 \%$ at a viral $\operatorname{load}$ of $4.5 \log 10 \mathrm{cp} / \mathrm{mL}$. At a viral

$76 \operatorname{load}$ of $2.6 \log 10 \mathrm{cp} / \mathrm{mL}$, the antigen test yielded a positive result at a rate of $5 \%$. In a

77 multivariate generalized linear model with viral RNA load and test type, the SARS-CoV-2

78 TMPRSS2 culture was not significantly different from the antigen test $(\mathrm{p}$-value $=0.953)$. Both

79 the SARS-CoV-2 TMPRSS2 culture and antigen test were significantly more likely to yield

80 positive results than SARS-CoV-2 VeroE6 culture (p-value $<0.001$ for both). Unlike the antigen

81 test, the RT-PCR assay showed very little overlap with SARS-CoV-2 TMPRSS2 culture,

82 yielding positive results at much lower viral loads.

84 As shown in Table 1, the antigen test demonstrated a sensitivity and specificity of $96.4 \%$ (95\%

85 CI: 82.3, 99.4) and 98.7\% (96.1, 99.7), respectively. The RT-PCR assay demonstrated a

86 sensitivity and specificity of $100 \%(87.7,100)$ and $95.5 \%(91.1,97.8)$, respectively. Based on the

87 study prevalence of $11.2 \%$, as determined by SARS-CoV-2 TMPRSS2 culture positivity and a

88 total specimen number of 251 (based on the total, evaluable specimen set utilized for the Veritor

89 EUA study), the positive predictive value (PPV) for the antigen test was 90.0\% (76.3, 97.6),

90 while the PPV for the RT-PCR assay was only $73.7 \%(60.8,85.3)$. 
medRxiv preprint doi: https://doi.org/10.1101/2020.10.02.20205708; this version posted October 5, 2020. The copyright holder for this preprint (which was not certified by peer review) is the author/funder, who has granted medRxiv a license to display the preprint in perpetuity.

SARS-CoV-2 antigen testing and infectioúsness

\section{DISCUSSION}

92 The results here show similar sensitivity between the SARS-CoV-2 antigen test and the SARS-

93 CoV-2 RT-PCR assay (96.4\% and $100 \%$, respectively) over a time range of $<8$ days post

94 symptom onset. However, the SARS-CoV-2 antigen test had a PPV of $90.0 \%$, whereas the RT-

95 PCR assay showed a PPV of only 73.7\%. In addition, the probit model for percent positivity

96 employed in this study showed considerable overlap between the antigen test and the SARS-

97 CoV-2 TMPRSS2 culture, with little overlap between the SARS-CoV-2 TMPRSS2 culture and

98 RT-PCR.

99

$100 \mathrm{Ct}$ values are inversely correlated with the viral load thresholds corresponding to infectious virus

101 isolation. Because limits of detection vary between RT-PCR assays, however, Ct values reported

102 by specific RT-PCR assays correspond to different viral RNA loads. ${ }^{6,7,20-25}$ Here we utilized the

103 Lyra assay to establish a probit model of percent positivity by viral load, which facilitates a

104 better comparison of these results with previous work. Recent studies involving upper respiratory

105 swab specimens reported no cases of COVID-19 with SARS-CoV-2 viral RNA loads below 4

$106 \log 10 \mathrm{cp} / \mathrm{mL}^{1,3,5,6,8,13,26,27}$ Other work has shown that specimens with viral RNA loads $\leq 6 \log 10$

$107 \mathrm{cp} / \mathrm{ml}$ have minimal or no culturable SARS-CoV-2 virus. ${ }^{3,5,28-30}$ Here, a low percent positivity (5-

108 10\%) was observed for the SARS-CoV-2 VeroE6- culture test below $6 \log 10 \mathrm{cp} / \mathrm{mL}$. The

109 SARS-CoV-2 TMPRSS2 culture test, however, showed 90\% positivity at $5.6 \log 10 \mathrm{cp} / \mathrm{mL}$.

110 Although antigen test had a larger distribution of positivity, it overlapped considerably with the

111 SARS-CoV-2 TMPRSS2 culture test and approached 90\% positivity at a viral RNA load of

112 6.4Log10. This is consistent with the WHO target product profile for priority diagnostics, which 
medRxiv preprint doi: https://doi.org/10.1101/2020.10.02.20205708; this version posted October 5, 2020. The copyright holder for this preprint (which was not certified by peer review) is the author/funder, who has granted medRxiv a license to display the preprint in perpetuity.

SARS-CoV-2 antigen testing and infectiousness

113 supports viral RNA load based methodologies and includes an acceptable limit of detection for

114 point-of-care tests of $6 \log 10 \mathrm{cp} / \mathrm{mL}^{31}$

115

116 As with other viruses, RT-PCR-based methodologies may be detecting SARS-CoV-2 RNA even

117 after infectious virus is no longer present; ${ }^{32-37}$ especially at time periods beyond 7 days from

118 symptom onset. ${ }^{1,3}$ For most patients with COVID-19, efforts to isolate live virus from upper

119 respiratory tract specimens have been unsuccessful $\geq 10$ days from symptom onset; it is unlikely

120 that these individuals pose a transmission risk to others. ${ }^{25}$ In addition, there is no evidence to date

121 that persistent or recurrent detection of viral RNA, following recovery from COVID-19, poses a

122 risk of SARS-CoV-2 transmission. ${ }^{25}$

123

124 This work highlights a key potential value of decentralized POC antigen-based testing and

125 furthers our understanding of the interpretation of antigen test results. Antigen testing facilitates

126 accurate and rapid detection of infectious individuals who may not require direct medical

127 management (due to mild/non-severe disease), but for whom infection control measures have the

128 potential to interrupt community transmission. While RT-PCR is highly sensitive when

129 compared to SARS-CoV-2 TMPRSS2culture, antigen testing also showed excellent sensitivity

130 (96.4\%) coupled with better PPV relative to RT-PCR (90.0 versus 73.7) and rapid time to results.

132 This study had limitations. It only included specimens from patients within seven days of

133 symptom onset. Several studies have demonstrated an inability to culture SARS-CoV-2 beyond

134 day eight, despite ongoing RT-PCR positivity. ${ }^{1,3,5}$ Serial sampling of COVID-19 patients is

135 needed to determine if there is a propensity to have viral antigen test positive results after a 
medRxiv preprint doi: https://doi.org/10.1101/2020.10.02.20205708; this version posted October 5, 2020. The copyright holder for this preprint (which was not certified by peer review) is the author/funder, who has granted medRxiv a license to display the preprint in perpetuity. SARS-CoV-2 antigen testing and infectiousness

136 negative result, as can sometimes be seen with RT-PCR tests. Results from this study likely

137 underestimate the difference in specificity between RT-PCR and antigen testing that would be

138 expected in a set that included specimens collected at later times post symptom onset. In this

139 study, while three subjects were antigen test false positives versus SARS-CoV-2 TMPRSS2

140 culture, as many as ten subjects were RT-PCR false positives versus culture (viral RNA loads

141 ranging from 2.6 to $5.4 \log 10$ copies $/ \mathrm{mL}$ ). Although the sample size was adequate in this study,

142 the confidence intervals in the probit model were too wide to establish a definitive viral load cut-

143 off. To improve the precision associated with the point estimates, either a larger study or a meta-

144 analysis, involving multiple studies, would be required. Also, there are limitations associated

145 with the use of culture positivity or viral RNA load as a surrogate for infectiousness or

146 transmissibility that require further investigation. Finally, it is unclear how well the results here

147 will extrapolate to the other antigen tests due to variability in limit of detection or other test

148 characteristics.

150 Conclusion

151 Point-of-care SARS-CoV-2 antigen tests have the potential to significantly change the public

152 health interventions needed to minimize the spread of COVID-19 by providing a better test to

153 identify individuals that are likely to be shedding infectious virus and therefore transmit SARS-

$154 \mathrm{CoV}-2$. This will allow for rapid identification of asymptomatic COVID-19 cases and inform

155 shorter periods of self-isolation for COVID-19 infected individuals. In addition, the low cost and

156 scalability in low and middle-income countries associated with antigen-based testing will be an

157 important tool in the diagnostic armamentarium to contain and suppress COVID-19 community

158 transmission. 
medRxiv preprint doi: https://doi.org/10.1101/2020.10.02.20205708; this version posted October 5, 2020. The copyright holder for this preprint (which was not certified by peer review) is the author/funder, who has granted medRxiv a license to display the preprint in perpetuity.

SARS-CoV-2 antigen testing and infectiousness

\section{ACKNOWLEDGEMENTS}

160 We thank the National Institute of Infectious Diseases, Japan, for providing VeroE6TMPRSS2

161 cells. We also thank Karen Eckert (Becton, Dickinson and Company, BD Life Sciences -

162 Diagnostic Systems) for her input on the content of this manuscript and editorial assistance and

163 Stanley Chao (Becton, Dickinson and Company, BD Life Sciences - Diagnostic Systems) for

164 statistical support. The individuals acknowledged here have no additional funding or additional

165 compensation to disclose. We are grateful to the study participants who allowed this work to be 166 performed.

\section{AUTHOR CONTRIBUTIONS}

169 All authors contributed to the interpretation of the data, critically revised the manuscript for

170 important intellectual content, approved the final version to be published, and agree to be

171 accountable for all aspects of the work.

\section{FUNDING}

174 This study was funded by Becton, Dickinson and Company; BD Life Sciences_-Integrated

175 Diagnostics Solutions. Non-BD employee authors received research funds to support their work

176 for this study.

\section{POTENTIAL CONFLICTS OF INTEREST}

179 CKC, VP, JCA, SK, JL, DSG, and CR-D are employees of Becton, Dickinson and Company

180 AP-None

181 ML-None

182 YM-None 
medRxiv preprint doi: https://doi.org/10.1101/2020.10.02.20205708; this version posted October 5, 2020. The copyright holder for this preprint (which was not certified by peer review) is the author/funder, who has granted medRxiv a license to display the preprint in perpetuity.

SARS-CoV-2 antigen testing and infectiousness

\section{REFERENCES}

1841 Bullard, J. et al. Predicting infectious SARS-CoV-2 from diagnostic samples. Clinical infectious diseases : an official publication of the Infectious Diseases Society of America,

1872 Mina, M. J., Parker, R. \& Larremore, D. B. Rethinking Covid-19 Test Sensitivity — A Strategy for Containment. New England Journal of Medicine,

1903 Wolfel, R. et al. Virological assessment of hospitalized patients with COVID-2019. Nature 581, 465-469, doi:10.1038/s41586-020-2196-x (2020).

1924 Widders, A., Broom, A. \& Broom, J. SARS-CoV-2: The viral shedding vs infectivity 193 dilemma. Infect Dis Health 25, 210-215, doi:10.1016/j.idh.2020.05.002 (2020).

1945 La Scola, B. et al. Viral RNA load as determined by cell culture as a management tool for discharge of SARS-CoV-2 patients from infectious disease wards. Eur J Clin Microbiol

1976 Huang, C. G. et al. Culture-Based Virus Isolation To Evaluate Potential Infectivity of 198 Clinical Specimens Tested for COVID-19. J Clin Microbiol 58, doi:10.1128/JCM.01068$20(2020)$.

2007 Gniazdowski, V. et al. Repeat COVID-19 Molecular Testing: Correlation with Recovery of Infectious Virus, Molecular Assay Cycle Thresholds, and Analytical Sensitivity.

2038 Arons, M. M. et al. Presymptomatic SARS-CoV-2 Infections and Transmission in a Skilled Nursing Facility. N Engl J Med 382, 2081-2090, doi:10.1056/NEJMoa2008457

2069 Young, S. et al. Clinical evaluation of BD Veritor SARS-CoV-2 point-of-care test performance compared to PCR-based testing and versus the Sofia 2 SARS Antigen point-

20910 Morawska, L. \& Cao, J. Airborne transmission of SARS-CoV-2: The world should face 210 the reality. Environ Int 139, 105730, doi:10.1016/j.envint.2020.105730 (2020). 
medRxiv preprint doi: https://doi.org/10.1101/2020.10.02.20205708; this version posted October 5, 2020. The copyright holder for this preprint (which was not certified by peer review) is the author/funder, who has granted medRxiv a license to display the preprint in perpetuity.

SARS-CoV-2 antigen testing and infectiousness

21111 McAloon, C. et al. Incubation period of COVID-19: a rapid systematic review and meta212 analysis of observational research. BMJ Open 10, e039652, doi:10.1136/bmjopen-2020$213039652(2020)$.

21412 Griffin, J. M. et al. A rapid review of available evidence on the serial interval and 215 generation time of COVID-19. medRxiv, 2020.2005.2008.20095075, 216 doi:10.1101/2020.05.08.20095075 (2020).

21713 He, X. et al. Temporal dynamics in viral shedding and transmissibility of COVID-19. Nat $218 \quad$ Med 26, 672-675, doi:10.1038/s41591-020-0869-5 (2020).

21914 Byrne, A. W. et al. Inferred duration of infectious period of SARS-CoV-2: rapid scoping 220 review and analysis of available evidence for asymptomatic and symptomatic COVID-19

22215 Sia, S. F. et al. Pathogenesis and transmission of SARS-CoV-2 in golden hamsters.

$223 \quad$ Nature 583, 834-838, doi:10.1038/s41586-020-2342-5 (2020).

22416 BinaxNOWTM COVID-19 Ag CARD [package insert, EUA]. Abbott Diagnostics

225 Scarborough, Inc., Scarborough, MA; (2020).

22617 LumiraDx ${ }^{\text {TM }}$ SARS-CoV-2 Ag Test [package insert, EUA]. LumiraDx Group Limited, 227 Dumyat Business Park Alloa FK10 2PB, UK (2020).

22818 BD Veritor ${ }^{\mathrm{TM}}$ System for Rapid Detection of SARS-CoV-2 [package insert, EUA].

229 Becton, Dickinson and Company, Sparks-Glencoe, MD; (2020).

23019 Sofia® SARS Antigen FIA [package insert, EUA]. Quidel Corporation. San Diego, CA; $231 \quad$ (2020).

23220 Jacot, D., Greub, G., Jaton, K. \& Opota, O. Viral load of SARS-CoV-2 across patients 233 and compared to other respiratory viruses. Microbes Infect, 2020.2007.2015.20154518, 234 doi:10.1016/j.micinf.2020.08.004 (2020).

23521 La Marca, A. et al. Testing for SARS-CoV-2 (COVID-19): a systematic review and 236 clinical guide to molecular and serological in-vitro diagnostic assays. Reprod Biomed 237 Online 41, 483-499, doi:10.1016/j.rbmo.2020.06.001 (2020). 
medRxiv preprint doi: https://doi.org/10.1101/2020.10.02.20205708; this version posted October 5, 2020. The copyright holder for this preprint (which was not certified by peer review) is the author/funder, who has granted medRxiv a license to display the preprint in perpetuity.

SARS-CoV-2 antigen testing and infectiousness

23822 van Kasteren, P. B. et al. Comparison of seven commercial RT-PCR diagnostic kits for

239 COVID-19. J Clin Virol 128, 104412, doi:10.1016/j.jcv.2020.104412 (2020).

24023 Vogels, C. B. F. et al. Analytical sensitivity and efficiency comparisons of SARS-CoV-2

241 RT-qPCR primer-probe sets. Nat Microbiol 5, 1299-1305, doi:10.1038/s41564-020-

$242 \quad$ 0761-6 (2020).

24324 Dinnes, J. et al. Rapid, point-of-care antigen and molecular-based tests for diagnosis of

244 SARS-CoV-2 infection. The Cochrane database of systematic reviews 8, CD013705, 245 doi:10.1002/14651858.CD013705 (2020).

$24625 \quad$ CDC. Duration of Isolation and Precautions for Adults with COVID-19. Figure 5.

247 Updated September 10, 2020. https://www.cdc.gov/coronavirus/2019-ncov/hcp/duration248 isolation.html (Last accesssed 9/11/2020).

24926 Cevik, M., Bamford, C. G. G. \& Ho, A. COVID-19 pandemic-a focused review for 250 clinicians. Clin Microbiol Infect 26, 842-847, doi:10.1016/j.cmi.2020.04.023 (2020).

25127 Savvides, C. \& Siegel, R. Asymptomatic and presymptomatic transmission of SARS-

252 CoV-2: A systematic review. medRxiv, doi:10.1101/2020.06.11.20129072 (2020).

25328 Larremore, D. B. et al. Test sensitivity is secondary to frequency and turnaround time for 254 COVID-19 surveillance. medRxiv, doi:10.1101/2020.06.22.20136309 (2020).

25529 Quicke, K. et al. Longitudinal Surveillance for SARS-CoV-2 RNA Among Asymptomatic Staff in Five Colorado Skilled Nursing Facilities: Epidemiologic,

$25830 \quad$ van Kampen, J. J. A. et al. Shedding of infectious virus in hospitalized patients with 259 coronavirus disease-2019 (COVID-19): duration and key determinants. medRxiv, $260 \quad 2020.2006 .2008 .20125310$, doi:10.1101/2020.06.08.20125310 (2020).

26131 WHO. COVID-19 Target product profiles for priority diagnostics to support response to 262 the COVID-19 pandemic v.0.1 Released July 31,

263 https://www.who.int/publications/m/item/covid-19-target-product-profiles-for-priority264 diagnostics-to-support-response-to-the-covid-19-pandemic-v.0.1 (2020). 
medRxiv preprint doi: https://doi.org/10.1101/2020.10.02.20205708; this version posted October 5, 2020. The copyright holder for this preprint (which was not certified by peer review) is the author/funder, who has granted medRxiv a license to display the preprint in perpetuity.

SARS-CoV-2 antigen testing and infectiousness

26532 Peiris, J. S. et al. Clinical progression and viral load in a community outbreak of 266 coronavirus-associated SARS pneumonia: a prospective study. Lancet 361, 1767-1772, doi:10.1016/s0140-6736(03)13412-5 (2003).

26833 Chan, K. H. et al. Detection of SARS coronavirus in patients with suspected SARS. Emerging infectious diseases 10, 294-299, doi:10.3201/eid1002.030610 (2004).

Oh, M. D. et al. Viral Load Kinetics of MERS Coronavirus Infection. $N$ Engl J Med 375, 1303-1305, doi:10.1056/NEJMc1511695 (2016).

27235 Wang, Y. et al. Factors Associated With Prolonged Viral Shedding in Patients With Avian Influenza A(H7N9) Virus Infection. J Infect Dis 217, 1708-1717, doi:10.1093/infdis/jiy115 (2018).

Sissoko, D. et al. Persistence and clearance of Ebola virus RNA from seminal fluid of Ebola virus disease survivors: a longitudinal analysis and modelling study. The Lancet. Global health 5, e80-e88, doi:10.1016/S2214-109X(16)30243-1 (2017).

Paz-Bailey, G. et al. Persistence of Zika Virus in Body Fluids - Final Report. $N$ Engl J Med 379, 1234-1243, doi:10.1056/NEJMoa1613108 (2018).

Meng, X., Deng, Y., Dai, Z. \& Meng, Z. COVID-19 and anosmia: A review based on upto-date knowledge. American journal of otolaryngology 41, 102581, doi:10.1016/j.amjoto.2020.102581 (2020).

$28640 \quad$ Bossuyt, P. M. et al. STARD 2015: An Updated List of Essential Items for Reporting

28941 Lyra ${ }^{\circledR}$ SARS-CoV-2 Assay [package insert, EUA]. Quidel Corporation. Athens, OH; (2020).

29142 Matsuyama, S. et al. Enhanced isolation of SARS-CoV-2 by TMPRSS2-expressing cells.

Proc Natl Acad Sci U S A 117, 7001-7003, doi:10.1073/pnas.2002589117 (2020). 
medRxiv preprint doi: https://doi.org/10.1101/2020.10.02.20205708; this version posted October 5, 2020. The copyright holder for this preprint (which was not certified by peer review) is the author/funder, who has granted medRxiv a license to display the preprint in perpetuity.

SARS-CoV-2 antigen testing and infectiousness

29343 Waggoner, J. J. et al. Triplex Real-Time RT-PCR for Severe Acute Respiratory

294 Syndrome Coronavirus 2. Emerging infectious diseases 26, 1633-1635,

295 doi:10.3201/eid2607.201285 (2020).

29644 Wickham, H. ggplot2: Elegant Graphics for Data Analysis. Springer-Verlag New York, $297 \quad$ (2016).

$29845 \quad$ R Core Team . R: A language and environment for statistical computing. R Foundation 299 for Statistical Computing, Vienna, Austria. https://www.R-project.org/ (2020). 
medRxiv preprint doi: https://doi.org/10.1101/2020.10.02.20205708; this version posted October 5, 2020. The copyright holder for this preprint (which was not certified by peer review) is the author/funder, who has granted medRxiv a license to display the preprint in perpetuity. SARS-CoV-2 antigen testing and infectiousness

\section{METHODS}

301 Study design and specimen collection

302 Prospective specimen collection, specimen use, and participant demographics for the parent

303 study were described previously. ${ }^{9}$ This study involved the use of residual respiratory swab

304 specimens from the previous antigen test Food and Drug Administration-Emergency Use

305 Authorization (EUA) study, which occurred across 21 geographically diverse study sites, from

306 June 5-11, 2020. Briefly, eligible participants were $\geq 18$ years of age and had one or more self-

307 reported COVID-19 symptoms between 0-7 days from symptom onset. ${ }^{38,39}$ Nasal swab

308 specimens for use with antigen testing were collected only after the standard of care (SOC) swab.

309 Nasopharyngeal (NP) swab specimens were collected after the nasal swab specimen for use with

310 the RT-PCR assay (the laboratory reference standard in the EUA study); if an NP was collected

311 as part of the SOC procedure at a collection site, the participant was given the choice of having

312 an oropharyngeal (OP) swab specimen collected in lieu of a second NP swab for use with the

313 RT-PCR assay. Overall, 76 specimen sets (consisting of one nasal and either one NP or one OP

314 swab) were utilized from the original 251 evaluable specimen sets in the EUA study. The 76

315 specimens consisted of all 38 RT-PCR assay positive specimens, and 38, randomly selected RT-

316 PCR assay negative specimens from the parent study. Specimens for the RT-PCR assay

317 consisted of 71 NP swabs (37 and 34 positive and negative, respectively) and five OP swabs (1

318 and 4 positive and negative swabs, respectively). For the EUA study, reference testing was

319 performed at TriCore Reference Laboratories while the antigen testing was performed internally

320 at BD (San Diego, CA, USA). No study-related procedures were performed without an informed

321 consent process or signature of a consent form. This research was performed in alignment with 
medRxiv preprint doi: https://doi.org/10.1101/2020.10.02.20205708; this version posted October 5, 2020. The copyright holder for this preprint (which was not certified by peer review) is the author/funder, who has granted medRxiv a license to display the preprint in perpetuity.

SARS-CoV-2 antigen testing and infectiousness

322 principles set forth by Good Clinical Practice guidelines and the-Declaration of Helsinki. This

323 article was prepared according to STARD guidelines for diagnostic accuracy studies reporting. ${ }^{40}$

325 Test/assay procedures

326 Antigen test and RT-PCR assay

327 The antigen test (Becton, Dickinson and Company, BD Life Sciences-Integrated Diagnostic

328 Solutions, San Diego, CA) and RT-PCR assay (Quidel Corporation. Athens, OH) were

329 performed according to the manufacturers' IFU. ${ }^{19,41}$ The only exception was that nasal swabs

330 were shipped on dry ice $\left(-70^{\circ}\right)$ to the testing site prior to preparation for the antigen test. The RT-

331 PCR assay reports cycle number in a manner that omits the first 10 cycles; here cycle numbers

332 for the RT-PCR assay are reported with the addition of first 10 cycles.

\section{SARS-CoV-2 virus culture}

335 VeroE6TMPRSS2 was adapted from the VeroE6 cell line (ATCC CRL-1586) to express the

336 TMPRSS2 protease at levels approximately 10-fold higher than that found in the human lung. ${ }^{42}$

337 The cells were cultured in complete medium (CM) consisting of Dulbecco's modified Eagle

338 Medium, supplemented with 10\% fetal bovine serum (Thermo Fisher Scientific-Gibco,

339 Waltham, MA), 1mM glutamine (Thermo Fisher Scientific-Invitrogen, Waltham, MA), 1mM

340 sodium pyruvate (Thermo Fisher Scientific-Invitrogen, Waltham, MA), 100 $\mu \mathrm{g} / \mathrm{mL}$ penicillin

341 (Thermo Fisher Scientific-Invitrogen, Waltham, MA) and $100 \mu \mathrm{g} / \mathrm{mL}$ streptomycin (Thermo

342 Fisher Scientific-Invitrogen, Waltham, MA), at $37^{\circ} \mathrm{C}$ in a humidified chamber with $5 \%$ carbon

343 dioxide. Cells were grown to $75 \%$ confluence in a 24 well plate format and the CM was removed

344 and replaced with $150 \mu \mathrm{L}$ of infection media (IM) which is identical to CM but with the fetal 
medRxiv preprint doi: https://doi.org/10.1101/2020.10.02.20205708; this version posted October 5, 2020. The copyright holder for this preprint (which was not certified by peer review) is the author/funder, who has granted medRxiv a license to display the preprint in perpetuity. SARS-CoV-2 antigen testing and infectiousness

345 bovine serum reduced to $2.5 \%$. One hundred microliters $(100 \mu \mathrm{L})$ of the clinical specimen was

346 added to each assay well and the cells were incubated at $37^{\circ} \mathrm{C}$ for two hours. The inoculum was

347 then aspirated and replaced with $0.5 \mathrm{ml} \mathrm{IM}$; the cells were then maintained at $37^{\circ} \mathrm{C}$ for four days.

348 When a cytopathic effect was visible in most of the cells in a given well, the IM was harvested

349 and stored at $-70^{\circ} \mathrm{C}$. The presence of SARS-CoV-2 was confirmed through quantitative RT-PCR

350 as described previously, ${ }^{7,43}$ by extracting RNA from the cell culture supernatant using the Qiagen

351 viral RNA isolation kit and performing RT-PCR using the N1 and N2 SARS-CoV-2 specific

352 primers and probes in addition to primers and probes for human RNaseP gene using synthetic

353 RNA target sequences to establish a standard curve.

Probit models for probability of positive SARS-CoV-2 result

356 The RT-PCR assay was performed on serially diluted samples containing SARS-CoV-2 related

357 genomic RNA prepared in universal transport media (containing human lung epithelial cells at

358130,000 cells per $\mathrm{mL}$ ) at concentrations ranging from $1.27 \log 10$ copies $/ \mathrm{mL}$ (cp/ml) to 4.27

$359 \log 10 \mathrm{cp} / \mathrm{ml}$ (Table S1). The RT-PCR assay probability of positive result was fit using a probit

360 model linking the Lyra results to viral RNA load. Linear regression was performed linking $\log 10$

$361 \mathrm{cp} / \mathrm{ml}$ viral RNA load to Lyra Ct score using all samples with at least $3 \log 10 \mathrm{cp} / \mathrm{ml}$ (for which

362 observed Lyra positivity was $100 \%)$.

363

364 Antigen test positivity and SARS-CoV-2 TMPRSS2 culture positivity (a surrogate for

365 contagiousness), with RT-PCR confirmation, were fit with a probit model as a function of viral

366 load, using results from the Veritor EUA study; ${ }^{9}$ RT-PCR assay Ct scores were used to estimate

367 viral RNA loads, as described above. SARS-CoV-2 VeroE6 culture positivity linkage to viral 
medRxiv preprint doi: https://doi.org/10.1101/2020.10.02.20205708; this version posted October 5, 2020. The copyright holder for this preprint (which was not certified by peer review) is the author/funder, who has granted medRxiv a license to display the preprint in perpetuity.

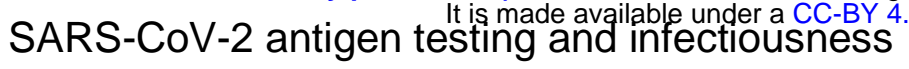

368 load was inserted into the probit model for probability of a positive result using data from Huang

369 et al (2020). ${ }^{6}$ Virus isolation in Huang et al was attempted for a total of 60 specimens, positive

370 by RT-PCR for SARS-CoV-2. Of those, 23 were positive by culture. Ct scores of the SARS-

371 CoV-2 envelope, nucleocapsid, and non-structural protein-12 RT-PCR targets were linked to the

372 viral $\operatorname{load}(\log 10 \mathrm{cp} / \mathrm{ml})$ through quadratic regressions. The empirical equation for envelope

373 target $\mathrm{Ct}$ score was then used to calculate viral load for the 23 culture positive and 37 culture

374 negative specimens (Figure S2). All analyses were performed using the R software system and

375 the ggplot2 R package. ${ }^{44,45}$ 
medRxiv preprint doi: https://doi.org/10.1101/2020.10.02.20205708; this version posted October 5, 2020. The copyright holder for this preprint (which was not certified by peer review) is the author/funder, who has granted medRxiv a license to display the preprint in perpetuity.

SARS-CoV-2 antigen testing and infectiousness

Table 1. Performance of the antigen test and the RT-PCR assay for detection of SARS-CoV-2 infectivity based on virus culture positive results within 0-7 days from symptom onset

Prevalence: $11.2 \%$

\begin{tabular}{lcc} 
Performance values & Antigen test performance & RT-PCR assay performance \\
\hline Sensitivity & $96.4[82.3,99.4]$ & $100[87.7,100]$ \\
\hline Specificity & $98.7[96.199 .7]$ & $95.5[91.1,97.8]$ \\
\hline PPV & $90.0[76.3,97.6]$ & $73.7[60.8,85.3]$ \\
\hline NPV & $99.5[97.7,100]$ & $100[98.4,100]$ \\
\hline Accuracy & $98.4[96.0,99.4]$ & $96.0[92.8,97.8]$ \\
\hline TP & 27 & 28 \\
\hline FP & 3 & 10 \\
\hline FN & 1 & 0 \\
\hline TN $^{\mathbf{a}}$ & 220 & 213
\end{tabular}

Abbreviations: RT-PCR, real-time polymerase chain reaction; PPV, positive predictive value; NPV, negative predictive value; TP, true positive; FP, false positive; $\mathrm{FN}$, false negative; $\mathrm{TN}$, true negative

$a_{\text {includes }} 176$ specimen sets that were RT-PCR and antigen negative, with unavailable culture results. 
medRxiv preprint doi: https://doi.org/10.1101/2020.10.02.20205708; this version posted October 5, 2020. The copyright holder for this preprint (which was not certified by peer review) is the author/funder, who has granted medRxiv a license to display the preprint in perpetuity.

SARS-CoV-2 antigen testing and infectiousness

488

409

410

411

412

413

414

415

416

417

418

419

420

421

422

423

424

425

426

427

428

429

430

431

432

433

434

435

436

437

438

439

440

441

442

443

444

445

446

447

448

449

450

451

452

453

454

455

456

457

FIGURES
FIGURE 1

Figure 1A.

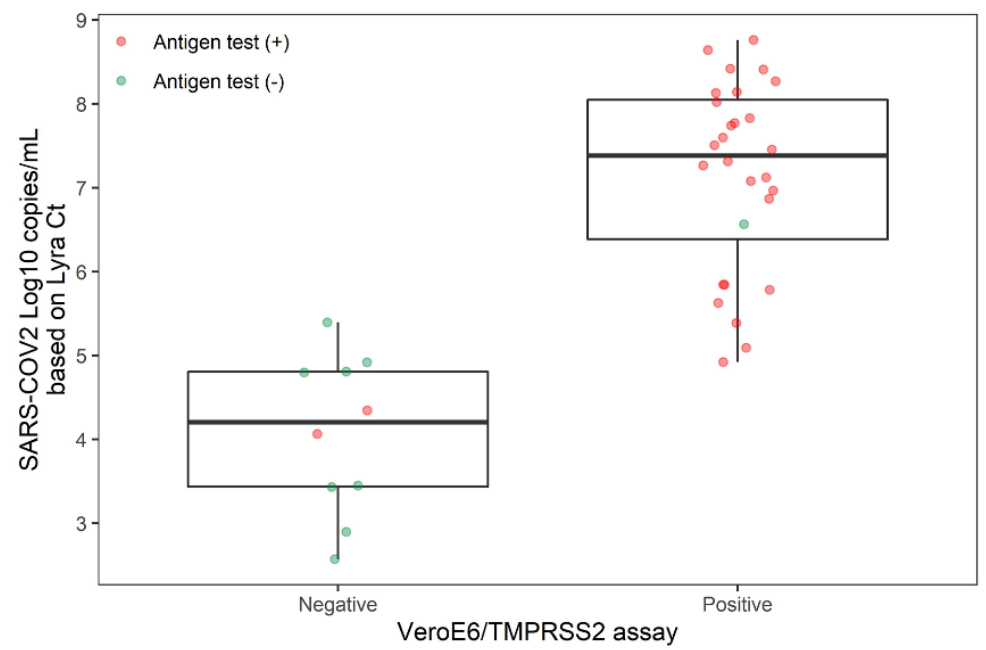

Figure 1B.

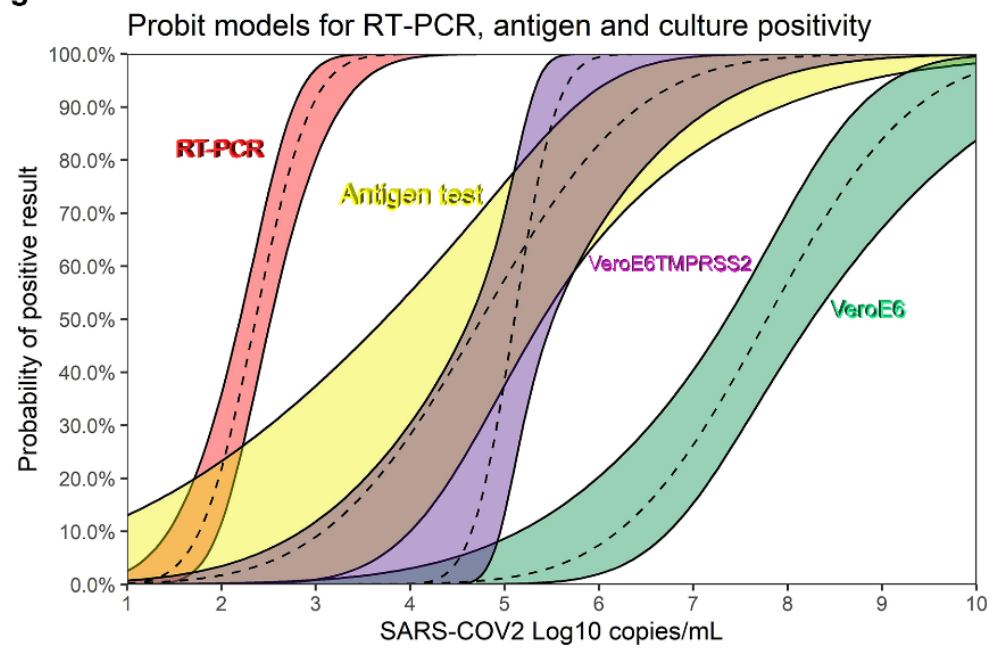

Figure 1. (A) The 38 RT-PCR assay positive specimens are plotted by $\log 10$ copies $/ \mathrm{mL}$ (y-axis) and are stratified by the SARS-CoV-2 live culture results (negative, $n=10$; positive, $n=28$ ). The median and inter-quartile range values, respectively, for the RT-PCR-positive/SARS-CoV-2 TMPRSS2 culture-negative were 4.21 and 1.37; the median and inter-quartile range values, respectively, for the RT-PCR-positive/SARS-CoV-2 TMPRSS2 culturenegative were 7.39 and 1.66. The mean values for the SARS-CoV-2 TMPRSS2 culture-negative and SARS-CoV-2 TMPRSS2 assay-positive specimen groups were significantly different (4.01 versus 7.16, respectively; p-value $<0.001$ based on two-sample t-test [2-tailed]). Antigen test positive results are indicated as red data points ( $\mathrm{n}=29)$ and the antigen test negative results $(n=9)$ are indicated by the green data points. (B) Probit models linking viral load to the probability of positive result of RT-PCR (Lyra), antigen test (Veritor), SARS-CoV-2 TMPRSS2 culture and SARS-CoV-2 VeroE6 culture (refer to Huang et al 2020). Viral load levels at which there is a $5 \%$ chance of positive result: 1.6, 2.6, 4.5, and $5.75 \log 10 \mathrm{cp} / \mathrm{ml}$ for RT-PCR, antigen, SARS-CoV-2 TMPRSS2 culture, and SARS-CoV-2 VEroE6 culture, respectively. 
medRxiv preprint doi: https://doi.org/10.1101/2020.10.02.20205708; this version posted October 5, 2020. The copyright holder for this preprint (which was not certified by peer review) is the author/funder, who has granted medRxiv a license to display the preprint in perpetuity.

SARS-CoV-2 antigen testing and infectiousness

458

460

461

462

463

464

465

466

467

468

469

470

471

472

473

474

475

476

SUPPLEMENTAL MATERIAL

TABLE S1

Table S1. Corresponding values for Ct score and viral RNA load during limit of detection analysis involving Lyra SARS-CoV-2 RT-PCR assay-positive specimens Viral Load Log10 \#Positive/ PCR assay (copies $/ \mathrm{mL}$ ) Viral Load \#Tested Ct score; Mean (SD)

\begin{tabular}{cccc}
\hline 0 & - & $0 / 5$ & $-(-)$ \\
\hline 19 & 1.27 & $0 / 9$ & $-(-)$ \\
\hline 40 & 1.60 & $1 / 10$ & $38.03(-)$ \\
\hline 86 & 1.94 & $1 / 9$ & $38.83(-)$ \\
\hline 186 & 2.27 & $4 / 10$ & $37.33(1.20)$ \\
\hline 400 & 2.60 & $8 / 10$ & $35.89(1.69)$ \\
\hline 862 & 2.94 & $8 / 10$ & $34.51(1.62)$ \\
\hline 1857 & 3.27 & $10 / 10$ & $32.66(1.07)$ \\
\hline 4000 & 3.60 & $10 / 10$ & $31.08(0.75)$ \\
\hline 8618 & 3.94 & $9 / 9$ & $30.09(1.15)$ \\
\hline 18566 & 4.27 & $9 / 9$ & $29.51(1.45)$ \\
\hline
\end{tabular}


medRxiv preprint doi: https://doi.org/10.1101/2020.10.02.20205708; this version posted October 5, 2020. The copyright holder for this preprint (which was not certified by peer review) is the author/funder, who has granted medRxiv a license to display the preprint in perpetuity.

SARS-CoV-2 antigen testing and infectiousness

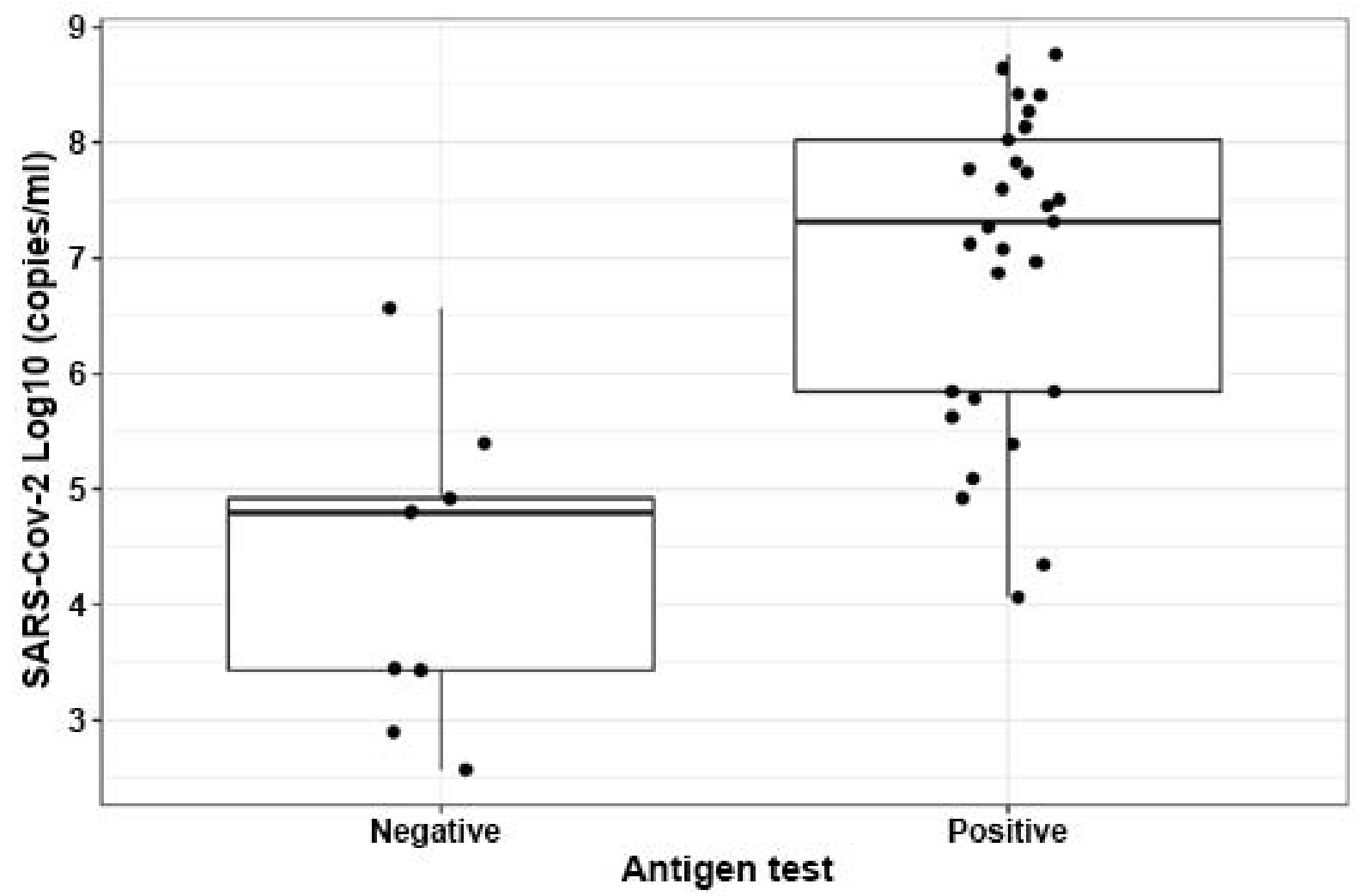

477 FIGURE S1

478 Figure S1. Box plots showing the median values for SARS-CoV-2 viral RNA loads from

479 antigen-positive and -negative results within the 38 RT-PCR-positive results from the

480 Veritor test EUA study. A two-sample t-test (2-tailed) analysis indicated a significantly

481 higher mean $(7.0 \log 10 \mathrm{cp} / \mathrm{ml})$ for RT-PCR-positive/antigen-positive results compared to

482 that $(4.3 \log 10 \mathrm{cp} / \mathrm{mL})$ for RT-PCR-positive/antigen negative results ( $p$-value $<0.001)$. 
Ct score link to SARS-COV2 copies/mL

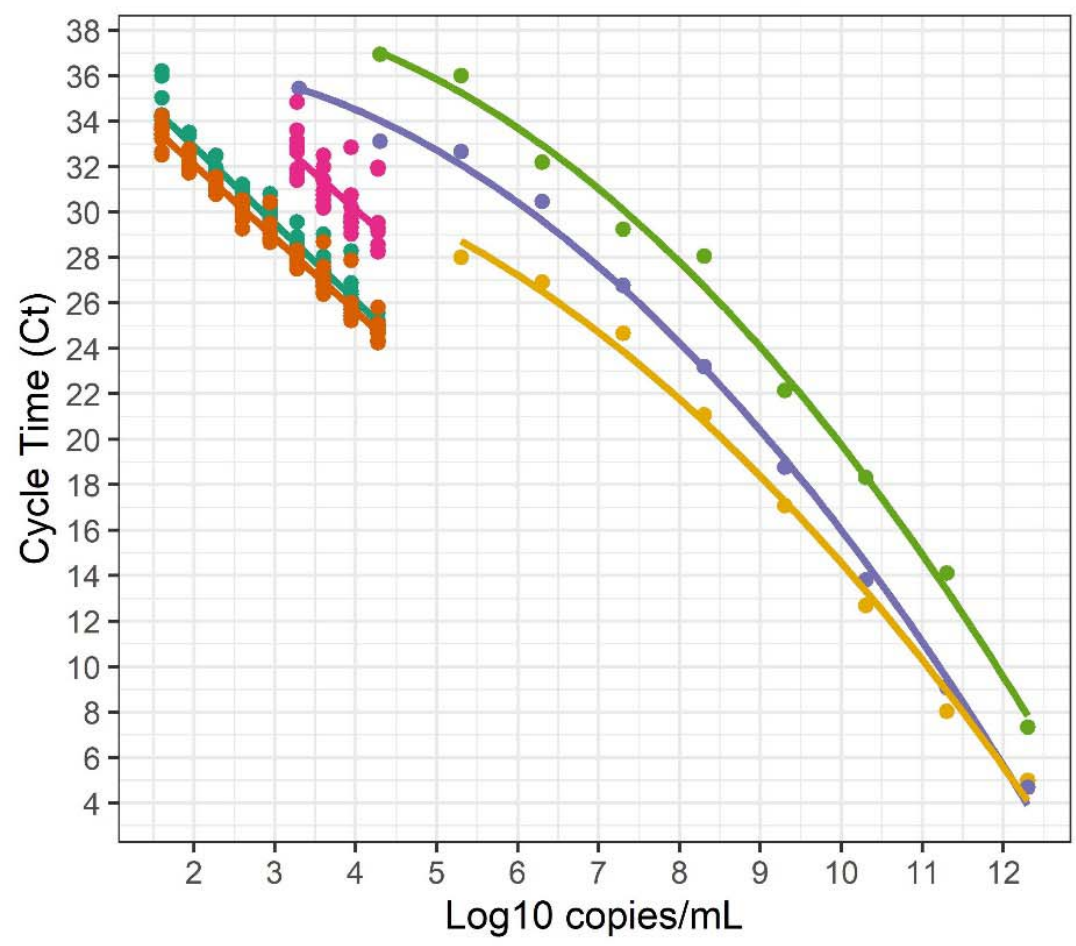

RT-PCR Target

$\rightarrow$ BD MAXN1

$\rightarrow$ BD MAXN2

$\rightarrow$ Lyra pp1ab

$=E$ (Huang 2020)

$\rightarrow N$ (Huang 2020)

$\approx$ nsp12 (Huang 2020)

FIGURE S2

Figure S2. Relation of the RT-PCR Ct scores for the BD MAX assay, the RT-PCR assay, and the RT-PCR method used in Huang et al $(2020)^{6}$ to viral load. Empirical

487 equation for the RT-PCR assay $\mathrm{Ct}=42.69-3.14 \mathrm{Log} 10$ copies $/ \mathrm{mL}$. Empirical equation

488 for the $\mathrm{E}$ target in Huang et al: $\log 10$ copies $/ \mathrm{mL}=12.377-0.052 \mathrm{Ct}-0.005 \mathrm{Ct}^{2}$ 